[Regular Paper]

\title{
Processing of Middle East Crude with Canadian Oil Sands Bitumen-derived Synthetic Crude Oil
}

\author{
Yoshikazu Sugimoto $^{\dagger 1), *}$, Yoichi Ainara ${ }^{\dagger 2)}$, Akimitsu Matsumura ${ }^{\dagger 1)}$, Akihiko OHI $^{\dagger 1)}$, Shinya SATO $^{\dagger 1)}$, \\ Ikuo SAITO $^{\dagger 1)}$, and Sok YuI ${ }^{\dagger 3), * *}$ \\ $\dagger^{11)}$ National Institute of Advanced Industrial Science and Technology (AIST), 1-1-1 Higashi, Tsukuba, Ibaraki 305-8565, JAPAN \\ †2) NEDO Fellow, National Institute of Advanced Industrial Science and Technology (AIST), \\ 1-1-1 Higashi, Tsukuba, Ibaraki 305-8565, JAPAN \\ †3) Syncrude Canada Ltd., 9421-17 Avenue, Edmonton, Alberta T6N 1H4, CANADA
}

(Received December 1, 2004)

\begin{abstract}
Light (LGO) and heavy or vacuum gas oil (VGO) fractions from mixed Middle East crudes and respective fractions from a typical Canadian oil sands bitumen-derived synthetic crude oil (SCO) were blended at various ratios (up to $40 \%$ ) and hydrotreated to investigate the kinetics of sulfur and nitrogen removal, and product quality. Hydrotreatment was carried out in down-flow micro reactors over commercially available $\mathrm{NiMo} / \mathrm{Al}_{2} \mathrm{O}_{3}$ and $\mathrm{CoMo} /$ $\mathrm{Al}_{2} \mathrm{O}_{3}$ catalysts, varying reactor temperature $\left(350-390^{\circ} \mathrm{C}\right)$, pressure $(5-10 \mathrm{MPa})$, and space velocity $\left(1-6 \mathrm{~h}^{-1}\right)$. Blending the LGO with SCO enhanced both sulfur and nitrogen removal from Middle East crude LGOs. Ultralow sulfur diesel $(<10 \mathrm{wtppm})$ meeting the Japanese cetane number $(C N)$ specification could be produced under reasonable operating conditions. Engine tests of the hydrotreated LGOs showed that the emissions of CO, HC, $\mathrm{NO}_{x}$, and PM (particulate matters) from a diesel engine were correlated with the fuel $C N$ and aromatics content. Hydrotreatment of blends of VGO and SCO led to lower sulfur content, but higher nitrogen content in the product oils. The estimated yields of FCC gasoline were slightly decreased by blending the SCO but not significantly.
\end{abstract}

\section{Keywords}

Exhaust emission, Fluid catalytic cracking, Hydrotreatment, Oil sands bitumen, Synthetic crude oil,

Ultra-low sulfur diesel

\section{Introduction}

As demand for oil is increasing, particularly in Asian countries, whereas the availability of conventional oil resources is declining, Canadian oil sands bitumen-derived synthetic crude oil ( $\mathrm{SCO}$ ) has recently attracted much attention as a promising alternative crude source. The Canadian oil sands resource holds about 1.6 trillion barrels of bitumen, of which about 175 billion barrels can be recovered by currently known in-situ and surface mining technologies ${ }^{1)}$. Syncrude Canada Ltd. and two other oil sands projects are now commercially operating in northern Alberta and many other projects are under development. Forecasts show that bitumen production from Canadian oil sands may increase from an average $920 \mathrm{~kb} / \mathrm{d}$ in 2003 to 1.8 million b/d by $2010^{1)}$.

At Syncrude, the bitumen is currently upgraded by two fluid cokers and an ebullated-bed hydrocracker, followed by processing in five hydrotreating units. The

\footnotetext{
$*, * *$ To whom correspondence should be addressed.

* E-mail: y-sugimoto@aist.go.jp

**E-mail: yui.sok@syncrude.com
}

hydrotreated products are combined as SCO and transported by pipeline to various refineries in North America. The typical properties of bitumen, coker products, hydrocracker products, and SCO are reported elsewhere $^{2)}$. The key features are that compared to conventional crude oils, the SCO contains no residues and very low sulfur but relatively large amounts of nitrogen and aromatics, and the cetane number $(C N)$ of the diesel fraction is low ${ }^{2)}$.

Regulation of sulfur in diesel and gasoline to around 10 wtppm is likely to occur within a few years to suppress air pollution in urban areas. Much research is now focused on developing new active catalysts and/or modification processes to provide such ultra-low sulfur

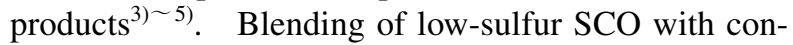
ventional crudes may be another approach. In this case, since the SCO quality is unique, the effect of processing the blended crudes on the refinery operation, product quality and environmental impact must be understood.

Pilot plant hydrotreatment experiments with the middle distillate from the SCO were conducted to investigate the kinetics of aromatics hydrogenation and the 
Table 1 Properties of Feedstocks for Hydrotreatment Tests

\begin{tabular}{|c|c|c|c|c|c|c|c|c|}
\hline & & \multicolumn{5}{|c|}{ Light gas oil } & \multicolumn{2}{|c|}{ Vacuum gas oil } \\
\hline & & LGO-A & LGO-B & LGO-C & $\mathrm{LCO}$ & OSL & VGO & OSV \\
\hline Density at $15^{\circ} \mathrm{C}$ & {$[\mathrm{g} / \mathrm{m} l]$} & 0.856 & 0.851 & 0.852 & 0.911 & 0.868 & 0.912 & 0.933 \\
\hline Sulfur & [wtppm] & 12100 & 12000 & 10000 & 2600 & 350 & 15500 & 2100 \\
\hline Nitrogen & [wtppm] & 190 & 110 & 170 & 230 & 114 & 700 & 1080 \\
\hline \multicolumn{9}{|c|}{ Hydrocarbon types by HPLC [wt $\%]$} \\
\hline Saturates & & 67.4 & 68.1 & 67.9 & 23.0 & 59.3 & 51.8 & 53.9 \\
\hline Aromatics & & 32.6 & 31.9 & 32.1 & 76.9 & 40.7 & 48.2 & 46.1 \\
\hline Mono- & & 14.9 & 15.2 & 14.9 & 27.2 & 33.0 & 24.9 & 17.2 \\
\hline Di- & & 15.8 & 14.9 & 15.8 & 42.4 & 7.3 & 16.9 & 19.8 \\
\hline Poly- & & 1.9 & 1.8 & 1.4 & 7.3 & 0.4 & 6.4 & 9.1 \\
\hline \multicolumn{9}{|c|}{ Distillation by ASTM D $2887 \quad\left[{ }^{\circ} \mathrm{C}\right]$} \\
\hline $5 \%$ & & 237 & 216 & 230 & 188 & 161 & 304 & 308 \\
\hline $10 \%$ & & 258 & 242 & 252 & 200 & 182 & 332 & 330 \\
\hline $20 \%$ & & 276 & 270 & 271 & 216 & 215 & 364 & 356 \\
\hline $30 \%$ & & 289 & 288 & 282 & 228 & 237 & 387 & 374 \\
\hline $50 \%$ & & 316 & 316 & 303 & 261 & 275 & 426 & 404 \\
\hline $70 \%$ & & 344 & 344 & 323 & 294 & 307 & 475 & 436 \\
\hline $80 \%$ & & 359 & 361 & 335 & 313 & 323 & 497 & 455 \\
\hline $90 \%$ & & 380 & 381 & 351 & 337 & 342 & 516 & 482 \\
\hline $95 \%$ & & 393 & 397 & 363 & 353 & 355 & 528 & 503 \\
\hline
\end{tabular}

product quality as diesel and jet fuels ${ }^{6}$. By further hydrotreatment, the aromatics content of the diesel fraction from SCO was reduced from 41 to $20 \%, C N$ was improved from 33 to 39 , and the smoke point of the jet fuel fraction was improved from 14 to $16 \mathrm{~mm}$ under typical conditions ${ }^{6}$. As part of the upgrading expansion stage 1 (UE-1) project, Syncrude has recently installed a new two-stage aromatics saturation unit, which is expected to result in diesel aromatics of 5\%, $C N$ of 48 , and jet fuel smoke point of $25 \mathrm{~mm}$. However, the quality of the overall diesel and jet fuels from $\mathrm{SCO}$ are still not adequate, so SCO distillates should be used as blending stocks.

In the present study, the light (LGO) and heavy or vacuum gas oil (VGO) fractions from mixed Middle East crudes and fractions from a typical SCO were blended at various ratios and hydrotreated over typical commercial NiMo and CoMo catalysts to investigate the kinetics of hydrodesulfurization (HDS) and hydrodenitrogenation (HDN). The CN of the LGO products and exhaust emissions from a diesel engine, and the quality of VGO products as fluid catalytic cracking (FCC) feeds were also investigated.

\section{Experimental}

\section{1. Hydrotreatment Tests}

\section{1. 1. Feedstocks and Catalysts}

Table 1 shows the properties of the feedstocks used in the present study. The properties of the blended feeds were determined using the blending ratios and the properties of the individual feed. The LGO-A, LGO-B, and VGO were derived from mixed Middle East crude oils and obtained from Japanese refineries.
The LGO-C was obtained by distilling the LGO-A to remove $20 \mathrm{wt} \%$ of the heavier cut. The LCO is a light cycle oil obtained from a commercial FCC unit processing typical mixed Middle East crudes. The OSL and OSV are light and vacuum gas oil fractions, respectively, from a typical SCO produced at the Syncrude bitumen upgrader ${ }^{2}$.

Compared to the LGO-A, the LGO-B is slightly lighter, and contains slightly less sulfur, nitrogen and aromatics. The LGO-C is also lighter and has lower sulfur, nitrogen and aromatics, because $20 \%$ of the heavier materials were removed. Compared to the LGO-A, B and C, the LCO is much heavier, although the mid-boiling point is lower, and contains much less sulfur and saturates, but more nitrogen and aromatics. The higher density may be related to the higher aromatics content. Compared to the LCO, the OSL contains much less sulfur and nitrogen, and relatively less aromatics. The oil sands-derived VGO (OSV) contains much less sulfur, but more nitrogen than the Middle East crude VGO (VGO). Both VGOs contain similar amounts of saturates and total aromatics, but the OSV contains less mono-aromatics and more di- and polyaromatics.

The catalysts used were two commercial NiMo/ $\mathrm{Al}_{2} \mathrm{O}_{3}\left(\mathrm{~A}\right.$ and $\mathrm{B}$ ) and a $\mathrm{CoMo} / \mathrm{Al}_{2} \mathrm{O}_{3}$ catalyst. Table 2 summarizes their nominal diameters, and chemical and physical properties.

\section{1. 2. Test Procedures}

Four runs of hydrotreatment tests were performed in three down-flow fixed-bed micro reactors, A and B (both identical; $9.4 \mathrm{~mm}$ i.d. and $500 \mathrm{~mm}$ overall length), and $\mathrm{C}$ (13 $\mathrm{mm}$ i.d. and $500 \mathrm{~mm}$ overall length). The objectives of the experiments and the catalysts used in 
Table 2 Catalyst Properties

\begin{tabular}{|c|c|c|c|}
\hline Catalysts & NiMo-A & NiMo-B & CoMo \\
\hline Nominal diameter & 1.3 & 1.6 & 1.3 \\
\hline \multicolumn{4}{|l|}{ Chemical composition [wt $\%$ dry basis] } \\
\hline Nickel & 3.0 & 3.0 & - \\
\hline Cobalt & - & - & 3.0 \\
\hline Molybdenum & 16.0 & 13.0 & 12.0 \\
\hline \multicolumn{4}{|l|}{ Physical properties } \\
\hline Surface area & 177 & 155 & 217 \\
\hline Pore volume & 0.35 & 0.47 & 0.45 \\
\hline Compact bulk density & 0.91 & 0.87 & 0.85 \\
\hline
\end{tabular}

Table 3 Summary of the Hydrotreatment Test Program

\begin{tabular}{|c|c|c|c|c|}
\hline Reactors (run \#) & A (run 1) & B (run 2) & $\mathrm{C}($ run 3$)$ & $\mathrm{C}$ (run 4) \\
\hline Purposes & $\begin{array}{l}\text { Study HDS \& HDN } \\
\text { reactivity }\end{array}$ & $\begin{array}{l}\text { Study HDS \& HDN } \\
\text { reactivity }\end{array}$ & $\begin{array}{l}\text { Produce samples for diesel } \\
\text { quality and emission study }\end{array}$ & $\begin{array}{l}\text { Study HDS \& HDN } \\
\text { reactivity, and FCC } \\
\text { performance }\end{array}$ \\
\hline \multicolumn{5}{|l|}{ Catalysts } \\
\hline Catalyst name & $\mathrm{NiMo} / \mathrm{Al}_{2} \mathrm{O}_{3}-\mathrm{A}$ & $\mathrm{CoMo} / \mathrm{Al}_{2} \mathrm{O}_{3}$ & $\mathrm{NiMo} / \mathrm{Al}_{2} \mathrm{O}_{3}-\mathrm{A}$ & $\mathrm{NiMo} / \mathrm{Al}_{2} \mathrm{O}_{3}-\mathrm{B}$ \\
\hline Weight & 3.64 & 3.40 & 16.56 & 5.22 \\
\hline Volume & 4.0 & 4.0 & 18.2 & 6.0 \\
\hline Dilution with $\mathrm{SiC}$ & yes & yes & no & yes \\
\hline Feeds & $\begin{array}{l}100 \% \text { ME crude LGOs, } \\
\text { and blends of LGO-C } \\
\text { with LCO \& OSL }\end{array}$ & $\begin{array}{l}100 \% \text { ME crude LGOs, } \\
\text { and blends of LGO-B } \\
\text { with OSL }\end{array}$ & $\begin{array}{l}\text { 100\% ME crude diesel } \\
\text { (GOB) \& OSL }\end{array}$ & $\begin{array}{l}100 \% \text { ME VGO, and } \\
\text { blends of VGO with } \\
\text { OSV }\end{array}$ \\
\hline \multicolumn{5}{|l|}{ Operating conditions } \\
\hline Feed rate $\quad[\mathrm{m} l / \mathrm{min}]$ & $0.08,0.1,0.14,0.2 \& 0.4$ & $0.1,0.14,0.2 \& 0.3$ & $0.6,1.0 \& 2.51$ & 0.1 \\
\hline LHSV $\quad\left[\mathrm{h}^{-1}\right]$ & $1.2,1.5,2.1,3.0 \& 6$ & $1.5,2.1,3.0 \& 4.5$ & $2.0,3.3 \& 8.3$ & 1.0 \\
\hline Temperature & 350 & 350 & $330,350,365 \& 390$ & $360,370 \& 380$ \\
\hline Pressure & 6 & 6 & $5,7.5 \& 10$ & $8,10 \& 12$ \\
\hline $\mathrm{H}_{2} /$ oil ratio $[\mathrm{Nm} l / \mathrm{m} l]$ & 250 & 250 & 250 & 500 \\
\hline
\end{tabular}

each reactor are summarized in Table 3. Run 3 was carried out in reactor $\mathrm{C}$ to produce sufficient amounts (about 15 liters each) of diesel fuels for the engine tests. The procedures will be explained in 2. 2. 1 .

All catalysts were dried at $400^{\circ} \mathrm{C}$ for $3 \mathrm{~h}$ and loaded in the reactors with the same volume of 36-mesh silicon carbide. The loaded catalyst was presulfided with LGO-A or LGO-B containing $2 \mathrm{wt} \%$ dimethyldisulfide (DMDS) over $24 \mathrm{~h}$, while the temperature was gradually raised from room temperature to $330^{\circ} \mathrm{C}$ for $16 \mathrm{~h}$ and maintained for $8 \mathrm{~h}$. After sulfiding, the feed containing DMDS was switched to clean LGO-A or LGO-B, and the temperature was increased to $370^{\circ} \mathrm{C}$ and maintained for five days to stabilize the catalyst activity.

Product samples were collected at 1-2 h intervals after stabilizing the catalyst more than $5 \mathrm{~h}$ under each set of conditions. Catalyst deactivation during the tests was assumed to be negligible. Any $\mathrm{H}_{2} \mathrm{~S}$ and $\mathrm{NH}_{3}$ trapped in the product sample were removed by passing nitrogen gas through the liquid before the product was analyzed. The reactor temperature was determined by a thermocouple located at the catalyst bed outlet. The reactor pressure was determined at the reactor inlet.

The sulfur and nitrogen contents were measured by an APS-35 analyzer. The boiling-point distribution was determined by gas chromatography (GC)-simulated distillation (ASTM D 2887). The hydrocarbon types were determined by high performance liquid chromatography (HPLC), supercritical fluid chromatography (SFC) or GC-MS (ASTM D 2786 \& D 3239).

\section{2. Diesel Engine Tests}

\section{2. 1. Sample Preparation}

Table 4 lists the six samples used for the engine tests. The GOA and GOB are mixed Middle East crudederived diesel cuts obtained from two refineries. The other four samples were produced by further hydrotreatment of the GOB and OSL over the presulfided NiMo/ $\mathrm{Al}_{2} \mathrm{O}_{3}$ - $\mathrm{A}$ catalyst in reactor $\mathrm{C}$ and blending as follows:

- GOB2: hydrotreatment of the GOB at $350^{\circ} \mathrm{C}, 8.3 \mathrm{~h}^{-1}$ and $5 \mathrm{MPa}$ in daytime, and at $330^{\circ} \mathrm{C}, 3.3 \mathrm{~h}^{-1}$ and $5 \mathrm{MPa}$ at night.

- GOB3: hydrotreatment of the GOB at $390^{\circ} \mathrm{C}, 3.3 \mathrm{~h}^{-1}$ and $10 \mathrm{MPa}$.

- OSL2: hydrotreatment of the OSL at $365^{\circ} \mathrm{C}, 3.3 \mathrm{~h}^{-1}$ and $7.5 \mathrm{MPa}$, and blending the hydrotreated OSL with the GOB2 at the $4: 6$ volume ratio.

- OSL3: hydrotreatment of the OSL at $390^{\circ} \mathrm{C}, 2 \mathrm{~h}^{-1}$ and $10 \mathrm{MPa}$, and blending the hydrotreated OSL with the GOB3 at the $4: 6$ volume ratio.

These blends were intended to make $\sim 10$ wtppm sul- 
Table 4 Properties of Diesel Fuels for Engine Test

\begin{tabular}{|c|c|c|c|c|c|c|c|}
\hline \multicolumn{2}{|l|}{ Sample name } & \multirow{2}{*}{$\frac{\text { GOA }^{a}}{0.829}$} & \multirow{2}{*}{$\frac{\mathrm{GOB}^{\mathrm{a})}}{0.828}$} & \multirow{2}{*}{$\frac{\mathrm{GOB}^{\mathrm{b}}{ }^{\mathrm{f}}}{0.824}$} & \multirow{2}{*}{$\frac{\left.\mathrm{GOB}^{\mathrm{b}}\right)}{0.809}$} & \multirow{2}{*}{$\frac{\left.\text { OSL2 }^{c}\right)}{0.838}$} & \multirow{2}{*}{$\frac{\text { OSL3 }^{\text {c) }}}{0.819}$} \\
\hline Density at $15^{\circ} \mathrm{C}$ & {$[\mathrm{g} / \mathrm{m} l]$} & & & & & & \\
\hline Sulfur & [wtppm] & 28 & 130 & 9 & $<1$ & 11 & 2 \\
\hline Nitrogen & [wtppm] & $<1$ & 1 & $<1$ & $<1$ & $<1$ & $<1$ \\
\hline Aniline point & {$\left[{ }^{\circ} \mathrm{C}\right]$} & 69.1 & 75.4 & 77.7 & 83.2 & 68.8 & 76.7 \\
\hline Cetane number by engine ${ }^{\mathrm{d})}$ & {$[-]$} & 53.2 & 60.4 & 62.5 & 65.8 & 48.1 & 56.3 \\
\hline Derived cetane number by IQT ${ }^{\mathrm{e})}$ & {$[-]$} & 53.4 & 55.7 & 59.1 & 62.7 & 49.8 & 54.9 \\
\hline \multicolumn{8}{|l|}{ Hydrocarbon types by HPLC } \\
\hline Saturates & & 72.2 & 76.5 & 81.4 & 93.5 & 75.9 & 91.9 \\
\hline Aromatics & & 27.8 & 23.5 & 18.6 & 6.5 & 24.1 & 8.1 \\
\hline Mono- & & 22.9 & 21.0 & 16.8 & 6.1 & 21.9 & 7.7 \\
\hline Di- & & 4.3 & 2.2 & 1.7 & 0.4 & 2.2 & 0.4 \\
\hline Poly- & & 0.6 & 0.3 & 0.1 & 0.0 & 0.0 & 0.0 \\
\hline \multicolumn{8}{|l|}{ Hydrocarbon types by SFC } \\
\hline Saturates & & 72.4 & 75.5 & 80.3 & 92.6 & 74.8 & 91.1 \\
\hline Aromatics & & 27.6 & 24.5 & 19.7 & 7.3 & 25.3 & 8.8 \\
\hline Mono- & & 22.3 & 21.1 & 17.5 & 6.7 & 22.2 & 8.1 \\
\hline Di- & & 4.7 & 3.2 & 2.1 & 0.6 & 2.9 & 0.7 \\
\hline Poly- & & 0.6 & 0.2 & 0.1 & 0.0 & 0.2 & 0.0 \\
\hline \multicolumn{8}{|c|}{ Distillation by ASTM D $2887 \quad\left[{ }^{\circ} \mathrm{C}\right]$} \\
\hline $5 \%$ & & 133 & 204 & 196 & 163 & 167 & 121 \\
\hline $10 \%$ & & 152 & 228 & 221 & 197 & 195 & 151 \\
\hline $20 \%$ & & 203 & 254 & 249 & 231 & 229 & 207 \\
\hline $30 \%$ & & 234 & 268 & 265 & 254 & 252 & 233 \\
\hline $50 \%$ & & 273 & 290 & 289 & 282 & 282 & 270 \\
\hline $70 \%$ & & 309 & 311 & 309 & 304 & 305 & 297 \\
\hline $80 \%$ & & 330 & 321 & 320 & 317 & 319 & 311 \\
\hline $90 \%$ & & 358 & 338 & 337 & 333 & 337 & 330 \\
\hline $95 \%$ & & 377 & 350 & 349 & 346 & 350 & 344 \\
\hline
\end{tabular}

a) GOA and GOB: Middle East crude origin diesel fuel cuts obtained from refineries A and B, respectively.

b) GOB2 and GOB3: Hydrotreated GOBs at different conditions.

c) OSL2 and OSL3: Blends of 40 vol\% of hydrotreated OSL, and 60 vol\% of GOB2 and GOB3, respectively.

d) JIS K 2280 or ASTM D 613.

e) Ignition quality tester (ASTM D 6890).

fur (GOB2 and OSL2) and < $10 \mathrm{wt} \%$ aromatics (GOB3 and OSL3) diesel fuels. The blending ratio of $4: 6$ was determined, assuming that no refinery will process more than $40 \%$ of oil sands-derived LGO.

\section{2. 2. Cetane Number and Exhaust Emission}

The $C N$ s were determined by an engine (JIS K 2280 or ASTM D 613) and ignition quality tester (IQT; ASTM D 6890). The exhaust emissions were determined with a medium-duty diesel vehicle (Toyota KJCR43V) of the following configuration:
Displacement: $2.184 l$

Gross vehicle weight: $2210 \mathrm{~kg}$

Maximum power: $58 \mathrm{~kW} / 4400 \mathrm{rpm}$

Transmission: 4AT (automatic transmission)

The engine conformed to the following Japanese FY1998 emission standards:

Carbon monoxide (CO): $2.10 \mathrm{~g} / \mathrm{km}$

Hydrocarbons (HC): $\quad 0.40 \mathrm{~g} / \mathrm{km}$

Nitrogen oxide $\left(\mathrm{NO}_{x}\right): \quad 0.70 \mathrm{~g} / \mathrm{km}$

Particulate matter (PM): $0.09 \mathrm{~g} / \mathrm{km}$

The accumulated mileage of the vehicle at the beginning of the test was about $6300 \mathrm{~km}$. The test method followed the 10/15 Mode Exhaust Emission Test
Procedure for Diesel-Powered Motor Vehicles (TRIAS 24-4-1993) specified by the Ministry of Land, Infrastructure and Transport of Japan. Each test was repeated three times and the average of the three was used as the result.

The chassis dynamometer used in the test vehicle was a 2-roller-type hydraulic dynamometer manufactured by Clayton. All exhaust gases were collected at a constant rate of $9 \mathrm{Nm}^{3} / \mathrm{min}$ from a dilution tunnelconstant volume sampler manufactured by Horiba, Ltd. The concentration of diluted exhaust gas was determined by a motor vehicle exhaust gas analyzer manufactured by Horiba. The PM was determined by collection on a $63 \mathrm{~mm}$ diameter Teflon-coated glass fiber filter (Pall Corp., Pallflex TX40HI20-WW), employing a PM collection unit manufactured by Horiba, and by weighing the collected PM on a semi-micro balance.

\section{Results and Discussion}

\section{1. Kinetics of HDS and HDN of LGOs}

The HDS and HDN data of the LGOs were analyzed based on the following power law kinetic equation, as- 

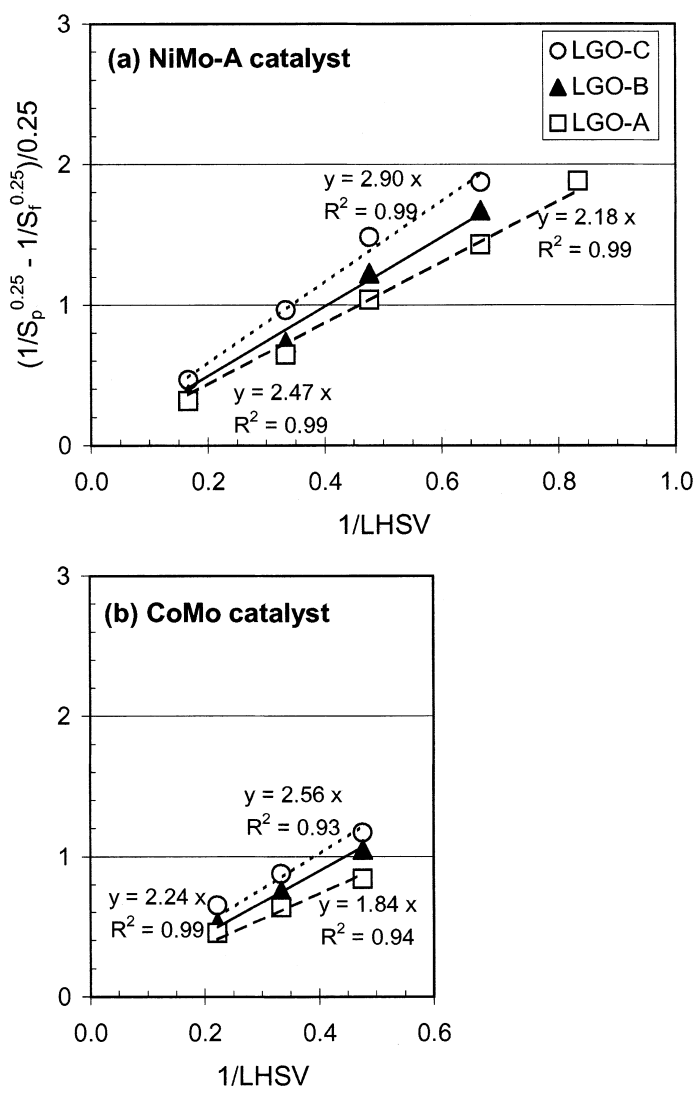

Fig. 1 1.25th-order HDS Rate Constants of Three Middle East Crude LGOs $\left(350^{\circ} \mathrm{C} ; 6 \mathrm{MPa} ; \mathrm{H}_{2} / \mathrm{oil}=250 \mathrm{Nm} l / \mathrm{m} l\right)$

suming plug flow:

$$
k=\frac{L H S V}{n-1}\left(\frac{1}{C_{\mathrm{p}}^{n-1}}-\frac{1}{C_{\mathrm{f}}^{n-1}}\right)
$$

where $k=$ rate constant; $L H S V=$ liquid hourly space velocity (vol of feed/h/vol of catalyst; $\mathrm{h}^{-1}$ ); $n=$ apparent reaction order; $C=$ sulfur or nitrogen content (wtppm); and subscripts $f$ and $p$ indicate feed and product, respectively.

Figures 1 (a) and (b) illustrate the results of HDS over NiMo-A and CoMo catalyst, respectively, assuming the best-fit reaction order of 1.25. A recent study on ultra-deep HDS of Middle East crude LGOs obtained the reaction order as $1.2^{4)}$, which agrees with our results. The slopes of the best-fit straight lines give the rate constants as defined by Eq. (1). The HDS reactivity depends on the content and structure of the sulfur compounds, and the content of inhibiting species such as nitrogen and polyaromatic compounds in the feeds ${ }^{7) \sim 9)}$. High boiling point gas oils contain more refractory sulfur compounds such as 4,6-dimethyldibenzothiophene, nitrogen and polyaromatics. LGO-A contains similar amounts of sulfur and highboiling components, but higher nitrogen than LGO-B. Such characteristics may explain the lower HDS reactivity of LGO-A than LGO-B.
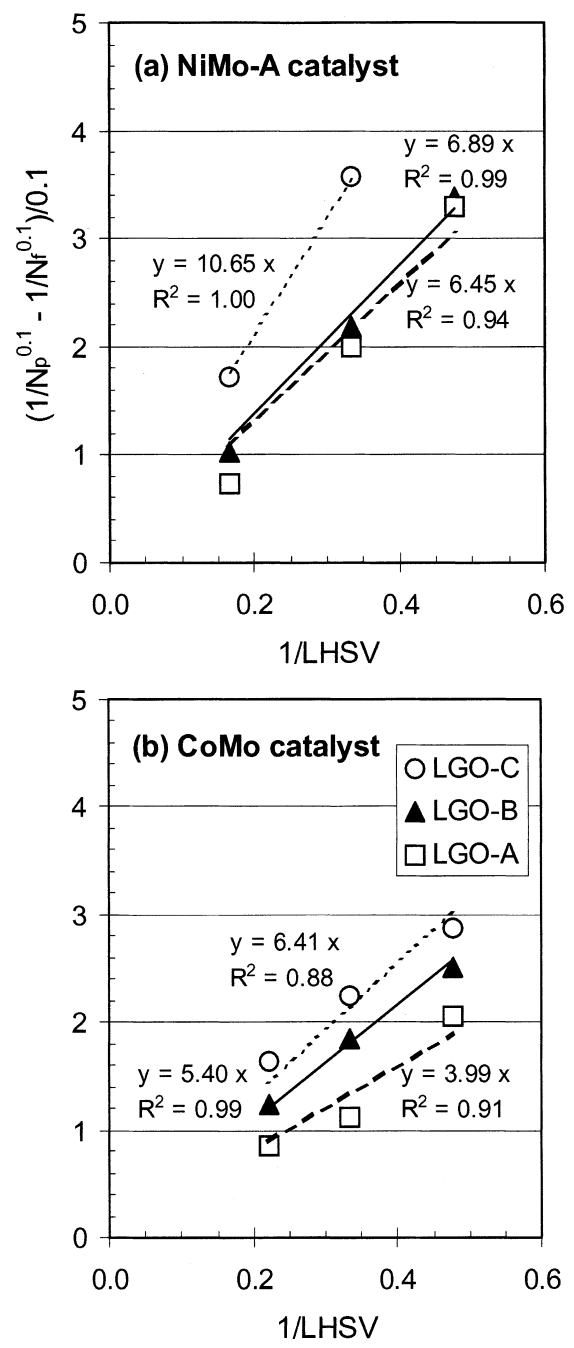

Fig. 2 1.1th-order HDN Rate Constants of Three Middle East Crude LGOs $\left(350^{\circ} \mathrm{C} ; 6 \mathrm{MPa} ; \mathrm{H}_{2} / \mathrm{oil}=250 \mathrm{Nm} l / \mathrm{ml}\right)$

LGO-C was obtained by removing $20 \mathrm{wt} \%$ of high boiling point components from LGO-A. The HDS rate constant $\left(k_{\mathrm{S}}\right)$ of LGO-C was increased by $33 \%$ (from 2.18 to 2.90 ) for the NiMo-A catalyst and $39 \%$ (from 1.84 to 2.56 ) for the CoMo catalyst. The rate constants with the NiMo catalyst were higher than that with the CoMo catalyst, i.e., $13 \%$ higher (2.90 vs. 2.56) for LGO-C, $10 \%$ (2.47 vs. 2.24) for LGO-B, and $34 \%$ (2.18 vs. 1.84) for LGO-A. These results suggest that the HDS activity of NiMo catalyst was enhanced for the feed (LGO-A) containing more nitrogen.

Figures 2 (a) and (b) illustrate the HDN data, assuming the best-fit reaction order of 1. 1. Data points of less than 1 wtppm were excluded from the analysis because of inaccuracy. Compared to the HDS data, some cases were still scattered with lower $R^{2} \mathrm{~S}$. This is mainly because the levels of product nitrogen are very low (close to 1 wtppm) and the quality of the data at this level is not good enough to obtain better correla- 
tions. Nevertheless, the following comments may be offered. Similar to HDS, LGO-C had the highest HDN rate constant $\left(k_{\mathrm{N}}\right)$ followed by LGO-B and LGO-A; and the NiMo-A catalyst provided a much higher $k_{\mathrm{N}}$ than the CoMo catalyst, i.e., $65 \%$ higher (11.25 vs. 6.83) for LGO-C, 26\% (7.33vs. 5.81) for LGO-B, and $57 \%$ (6.85 vs. 4.35) for LGO-A.

Instead of analyzing the HDS and HDN data with higher than 1st-order kinetics assuming plug flow as discussed above, the same data can be analyzed based on 1st-order kinetics assuming nonplug flow and employing a power term for space velocity ${ }^{10), 11)}$. By doing so, we obtained the power term as 0.6 , which is similar to that obtained previously ${ }^{10)}$. This suggests that the catalyst beds employed in the present study might not be completely wetted even though the beds were diluted with $\mathrm{SiC}^{12}$. Nevertheless, the relative reactivities among the feeds and between the two catalysts were the same as that calculated assuming plug flow.

\section{2. Effects of Removal of Heavy Ends, and Addition of LCO and OSL}

As shown in Fig. 1, removing heavy ends from the feedstock is an effective way to achieve higher $k_{\mathrm{S}}$ and, therefore, lower sulfur product (LGO-C vs. LGO-A). However, removing the heavy ends will result in insufficient production of diesel fuel, so other sources may be needed to compensate the imbalance. We assumed that $20 \mathrm{wt} \%$ of LCO (light cycle oil) and/or OSL ( $\mathrm{LGO}$ cut from $\mathrm{SCO}$ ) would be added to LGO-C to make the balance.

Figures 3 (a) and (b) illustrate the sulfur and nitrogen contents of the hydrotreated products obtained at various LHSVs (1.5-6 $\mathrm{h}^{-1}$ ) over NiMo-A catalyst, while maintaining other conditions constant. Data of less than 1 wtppm nitrogen were not shown in Fig. 3 (b). The best-fit 1.25 th-order rate constants $k_{\mathrm{S}}$ of LGO-A, LGO-C, and blends with $20 \%$ LCO, 20\% OSL, and $20 \%$ OSL $+20 \%$ LCO are 2.18, 2.90, 2.68, 3.13, and 2.96, respectively. Figures 3 (a) and (b) indicate the following. Ultra-low sulfur diesel (ULSD; $\sim 10$ wtppm $S$ ) could be produced from LGO-C as well as blends with LCO and OSL at $1.5 \mathrm{~h}^{-1} \mathrm{LHSV}$, but not from LGO-A at the same LHSV. The blend with $20 \mathrm{wt} \%$ OSL gave the product with the lowest sulfur content. Since the OSL contains much less sulfur, nitrogen and polyaromatics than LGO-C, blending of the OSL leads to lower sulfur and nitrogen levels in the product. The blend with $20 \mathrm{wt} \%$ LCO gave lower $k_{\mathrm{S}}$ (2.68) and higher sulfur level than $100 \%$ LGO-C, although the sulfur content of LCO (2600 wtppm) is lower than that of LGO-C (10000 wtppm). This was probably due to inhibition of the HDS reaction by the higher levels of nitrogen $(230 \mathrm{wtppm})$ and polyaromatic (7.3 wt\%) compounds in $\mathrm{LCO}^{13)}$ as shown in Table 1. If both $20 \mathrm{wt} \%$ OSL and $20 \mathrm{wt} \%$ LCO were added to
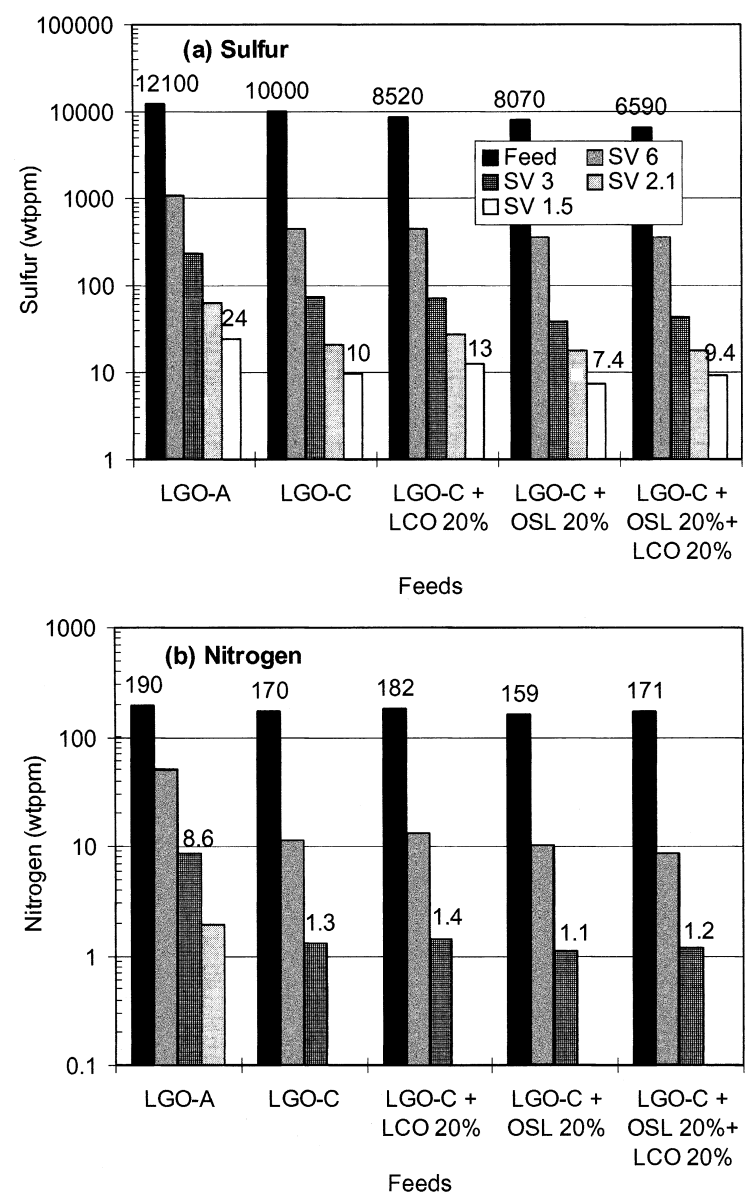

Fig. 3 Removing Heavier Cut from LGO-A and Blending OSL Produced Ultra-low Sulfur and Nitrogen Diesel (NiMo-A catalyst; $350^{\circ} \mathrm{C} ; 6 \mathrm{MPa} ; \mathrm{H}_{2} / \mathrm{oil}=250 \mathrm{Nm} l / \mathrm{ml}$ )

LGO-C, the sulfur level in the product fell between the $20 \%$ LCO case and $20 \%$ OSL case, as expected. LGO-C and blended feeds yielded product with 1 wtppm nitrogen content even at higher LHSV $\left(3 \mathrm{~h}^{-1}\right)$.

Figures 4 (a) and (b) illustrate the sulfur and nitrogen contents of the feeds and hydrotreated products over CoMo catalyst. Processing of only LGO-B could not produce ULSD over CoMo catalyst, but the blend with $40 \mathrm{wt} \%$ of OSL could produce USLD at $1.5 \mathrm{~h}^{-1}$ LHSV. By blending the LGO-B with $20 \%$ and $40 \%$ OSL, the 1.25 th-order $k_{\mathrm{S}}$ was increased by $14 \%$ and $36 \%$, respectively. OSL contains high levels of naphthenic and monoaromatic compounds and low levels of $C N$. Therefore, only OSL cannot be used as a diesel fuel, but must be used as a blending stock. If the OSL is blended with conventional crude LGO, ULSD can be produced more easily.

\section{3. LGO Quality as Diesel Fuel}

Table 4 summarizes the properties of the six LGOs tested, including cetane numbers by the engine test and IQT. According to ASTM, the reproducibility limits of $C N$ are 2.9 at average $48 C N$ and 3.3 at average 56 

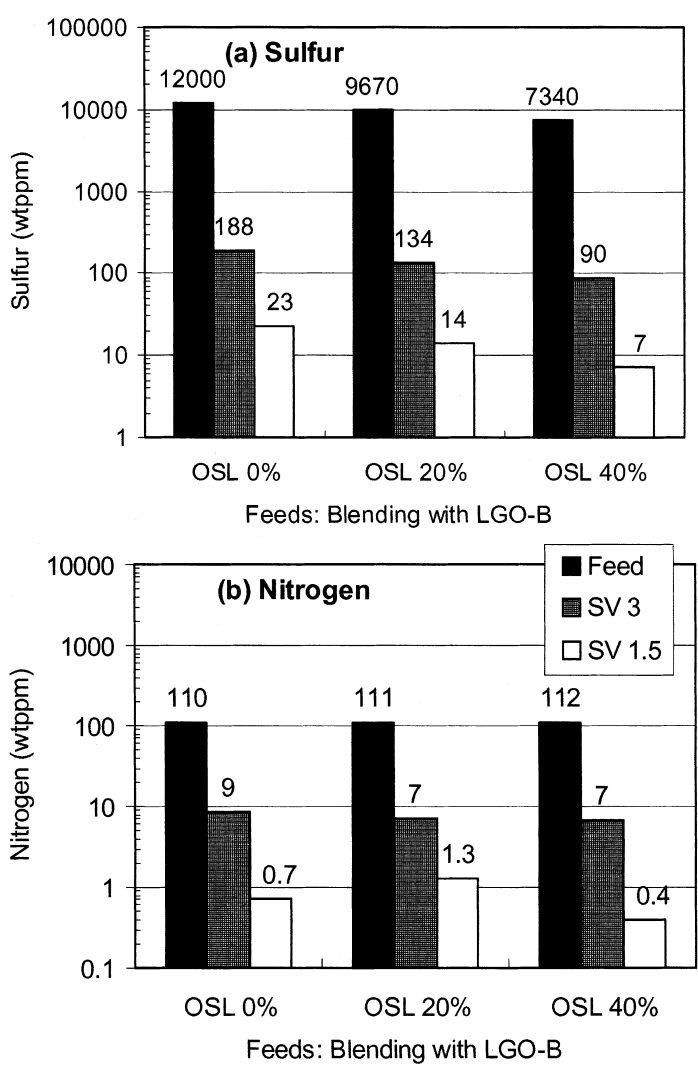

Fig. 4 Blending OSL with LGO-B also Produced Ultra Low-sulfur Diesel (CoMo catalyst; $350^{\circ} \mathrm{C} ; 6 \mathrm{MPa} ; \mathrm{H}_{2} /$ oil $=250 \mathrm{Nm} l / \mathrm{m} l$ )

$C N$ by D 613 (engine), and 4.47 at average $45 C N$ and 7.41 at average $63 C N$ by D 6890 (IQT). Thus, the quality of the $C N \mathrm{~s}$ is considered to be acceptable and the trends for the samples by each method are comparable.

As stated in section 2. 2. 1., GOA and GOB are commercially produced mixed Middle East crude-derived diesel cuts from different refineries, so the quality is considered to be typical of the current diesel fuel market in Japan.

Compared to GOB2 and OSL2, the corresponding GOB3 and OSL3 were produced under severer conditions, so the sulfur and aromatics contents were much lower, and the aniline point and $C N$ were higher. The aniline point is inversely related to the aromatics content within the same oil group.

Compared to GOB2 and GOB3, the corresponding OSL2 and OSL3 contain higher levels of aromatics and the $C N \mathrm{~s}$ are lower, but these fuels meet the current Japanese diesel specifications, i.e., $50 C N$ minimum in summer time and $45 C N$ minimum in winter time. Therefore, co-processing of oil sands-derived distillates up to 40 vol\% as in the present study could produce diesel fuel meeting the current specifications.

\section{4. Exhaust Emissions}

Figures 5 (a) to (d) illustrate the exhaust emissions of the six LGOs listed in Table 4. In general, among the four Middle East crude-derived LGOs, GOB emitted fewer emissions than GOA; hydrotreated LGO (GOB2) fewer than its untreated counterpart (GOB); and severely hydrotreated LGO (GOB3) fewer than their counterparts (GOB and GOB2). Some of the above trends, however, were not apparent for $\mathrm{HC}$ and $\mathrm{NO}_{x}$ emissions. Compared to GOB2 and GOB3, the emissions of the corresponding fuels blended with OSL (OSL2 and OSL3) increased for CO, HC, and PM, but decreased for $\mathrm{NO}_{x}$. More severely hydrotreated product (OSL3) emitted fewer emissions than its counterpart (OSL2). These results suggest that co-processing with oil sands-derived LGO up to $40 \mathrm{vol} \%$ had no adverse impact on emissions from the diesel fuels.

Investigation of the influence of fuel properties on the $\mathrm{NO}_{x}$ and PM emissions of a heavy-duty diesel engine using eight diesel fuels of conventional, oil sandsderived fuels and their blends found a definite trend towards higher $\mathrm{NO}_{x}$ and $\mathrm{PM}$ emissions as the fuel density, and poly and total aromatic levels increased ${ }^{14)}$. As part of the Japan Clean Air Program, parametric studies were conducted to clarify the factors determining emissions, employing a single cylinder engine and 20 model fuels ${ }^{15)}$. $\mathrm{NO}_{x}$ and PM emissions increased with increased aromatics content and $90 \%$ distillation, and 3-ring aromatics caused large increases in PM emissions regardless of the engine test conditions.

Figures 6 (a) to (d) illustrate the relationship between the four emissions versus total aromatics content and the engine $C N$. Clearly the emissions increased as aromatics content increased or $C N$ decreased, except that no relationship was found between $\mathrm{HC}$ versus aromatics, and $\mathrm{NO}_{x}$ versus $C N$.

Using a stepwise linear regression technique ${ }^{16)}$, correlations to predict exhaust emissions were developed using the fuel properties. The fuel properties selected as independent variables were the density, sulfur content, total aromatics, di- and poly-aromatics, and $C N$. Both forward and backward stepwise linear regression procedures were employed. These two techniques do not necessarily yield the same final regression model if there is multicollinearity between the independent variables. In this case, backward stepwise regression analysis was performed again using all independent variables obtained from the initial forward and backward stepwise regressions. The results so obtained were tested using multiple linear regression.

The following results were obtained:

$$
\begin{aligned}
& \mathrm{CO}(\mathrm{g} / \mathrm{km})=0.431+0.00235 \times P A-0.00187 \times \\
& C N\left(R^{2}=0.995 ; S E \text { of estimate }=0.001\right) \\
& \mathrm{HC}(\mathrm{g} / \mathrm{km})=0.0864-0.00128 \times P A-0.000525 \times \\
& C N\left(R^{2}=0.975 ; S E \text { of estimate }=0.001\right) \\
& \mathrm{PM}(\mathrm{g} / \mathrm{km})=0.0188+0.000992 \times T A \\
& \quad\left(R^{2}=0.994 ; S E \text { of estimate }=0.001\right)
\end{aligned}
$$

where $P A=$ di- and poly-aromatics by SFC (wt \%), 

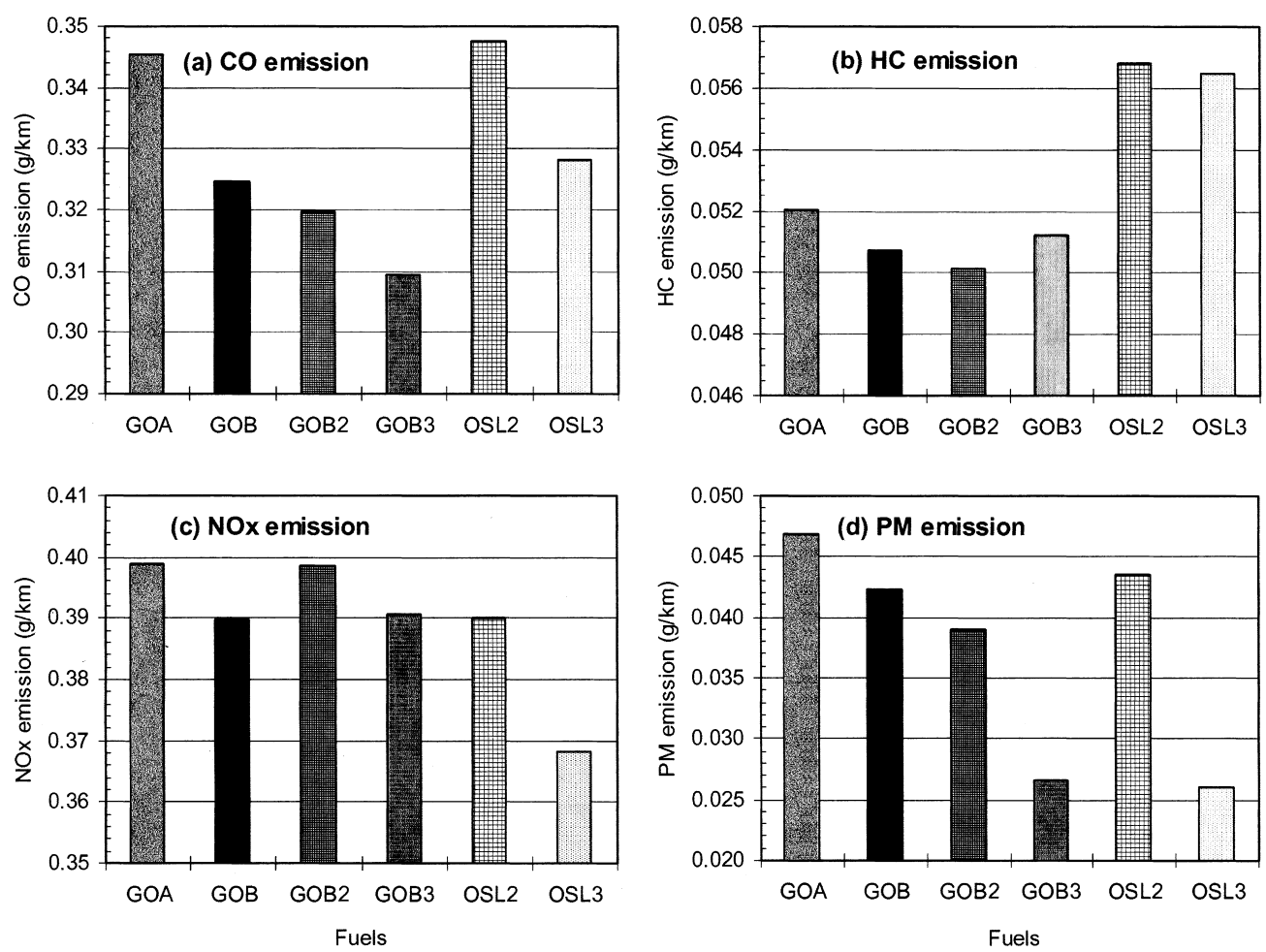

Fig. 5 Exhaust Emissions Vary Depending on Fuel
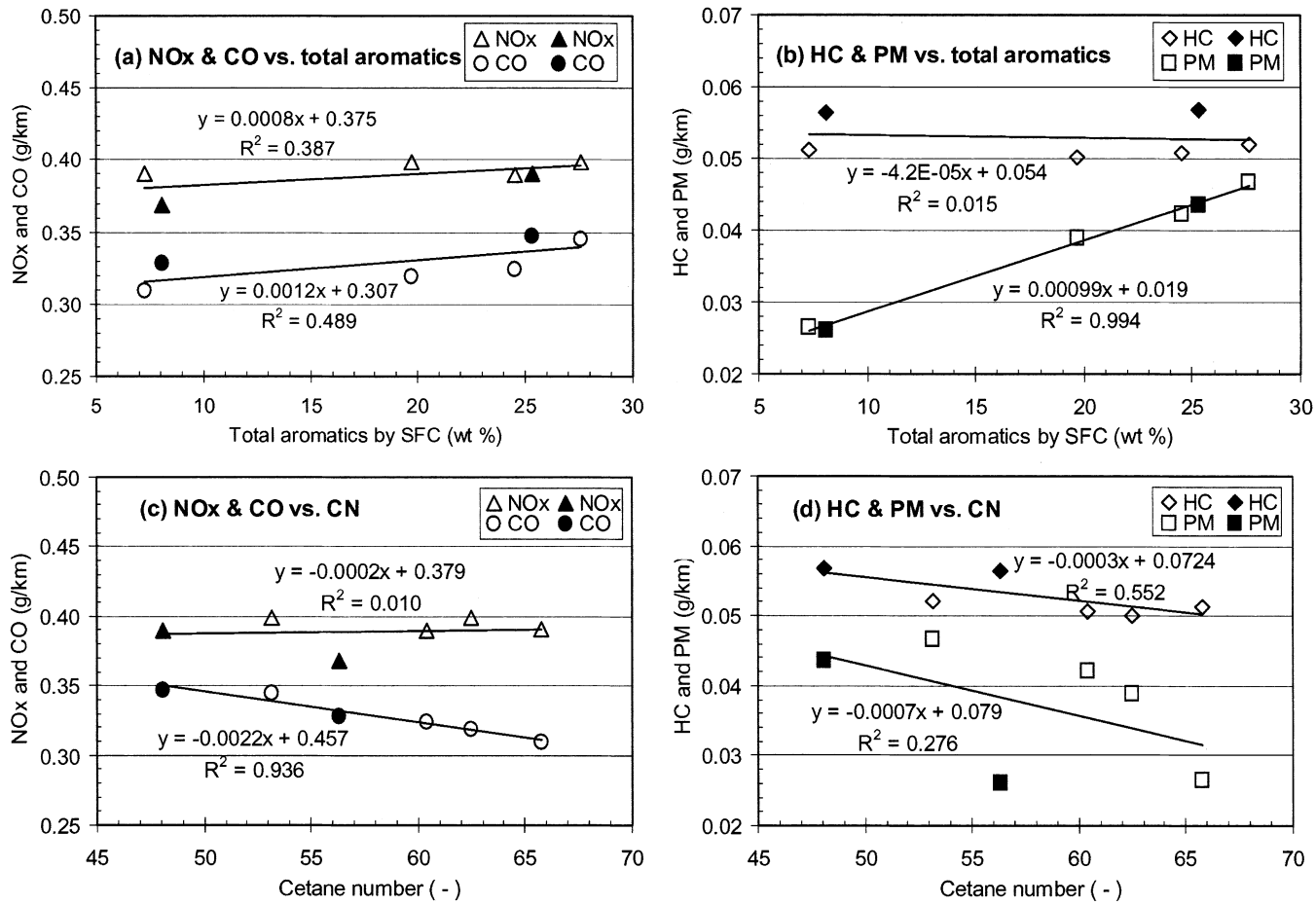

Fig. 6 Exhaust Emissions Vary Depending on Fuel Properties (open symbols: 100\% ME diesel; closed symbols: blends with OSL) 

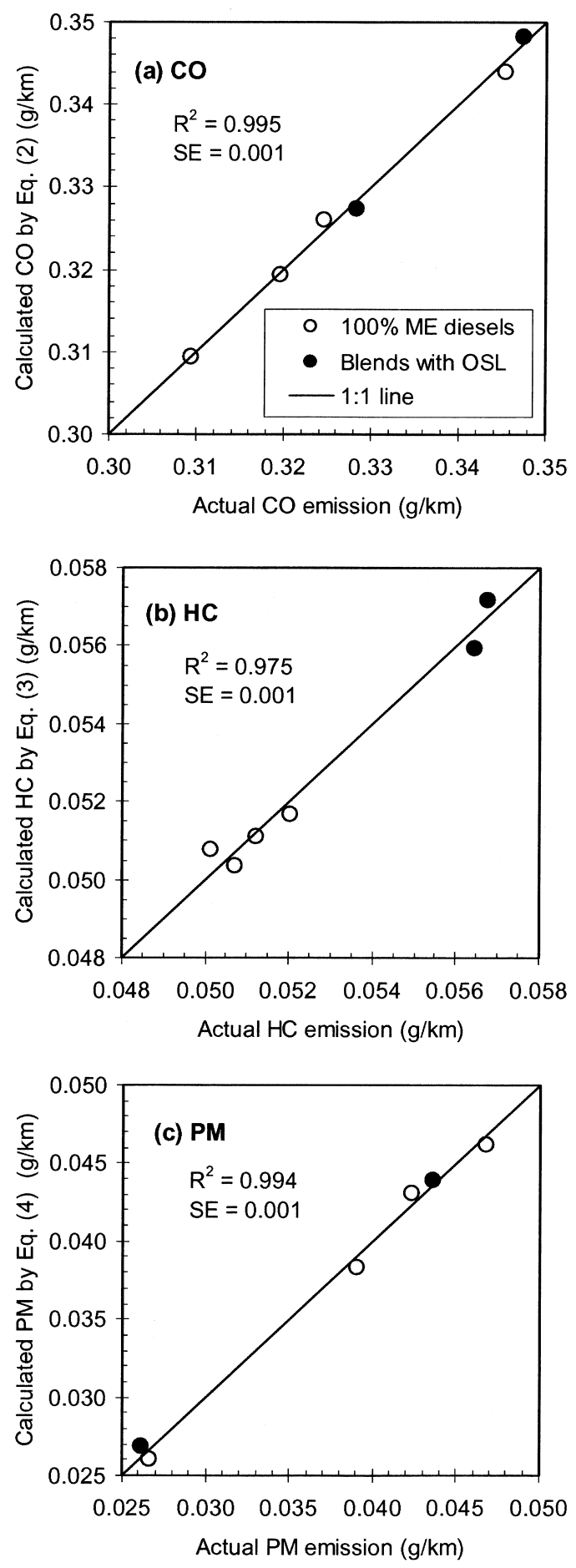

Fig. 7 Exhaust Emissions Can Be Predicted from Aromatics Content and Cetane Number (open symbols: 100\% ME diesel; closed symbols: blends with OSL)

$T A=$ total aromatics by SFC $(\mathrm{wt} \%)$, and $C N=$ cetane number by JIS K 2280. The standard error was 0.001 for all three equations and the $P$ values of each coefficient were less than 0.007 .

No correlation for $\mathrm{NO}_{x}$ with $P<0.05$ could be obtained. It is interesting to note that the sign of the $T A$
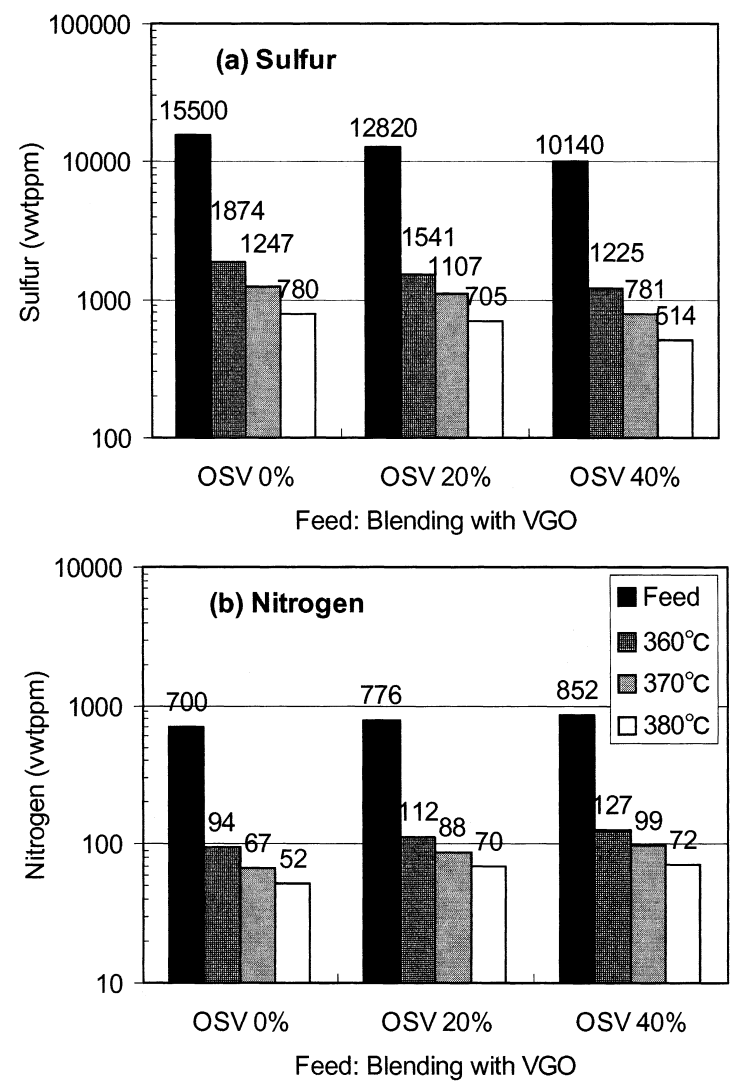

Fig. 8 Adding Oil Sands-derived VGO (OSV) to Middle East Crude VGO (VGO) Gives Lower Sulfur, but Higher Nitrogen Contents in Product (NiMo-B catalyst; LHSV $=1 \mathrm{~h}^{-1}$; $8 \mathrm{MPa} ; \mathrm{H}_{2} /$ oil $\left.=500 \mathrm{Nm} l / \mathrm{m} l\right)$

or $P A$ term was positive and that of the $C N$ term was negative, except for the $P A$ term for $\mathrm{HC}$ emission. Figures 7 (a) to (c) illustrate these results.

\section{5. Hydrotreatment of VGOs}

The feeds tested were 100\% Middle East crudederived vacuum gas oil (VGO), and two blends of the VGO with 20 and $40 \mathrm{wt} \%$ of oil sands-derived vacuum gas oil (OSV). The feed properties, operating conditions, and product properties are summarized in Table 5. The properties of the blended feeds were calculated using the properties of $100 \%$ VGO and OSV given in Table $\mathbf{1}$ and the blending ratios.

Figures 8 (a) and (b) illustrate the sulfur and nitrogen contents of the feeds and products obtained at different reaction temperature. As the blending ratio of OSV increased, the feed and product sulfur contents decreased, whereas the nitrogen content increased.

\section{6. Hydrotreated VGOs as FCC Feeds}

Hydrotreated VGO products are mainly used as FCC feeds, primarily for gasoline production. Lower sulfur content in the FCC feed results in lower sulfur content in the gasoline and other products. Therefore, decreased sulfur content in the FCC feed caused by blending with OSV is beneficial to produce low-sulfur FCC 
Table 5 Properties of Feeds, Hydrotreatment Conditions (NiMo-B Catalyst), Properties of Hydrotreated Products, and Predicted FCC Product Yields

\begin{tabular}{|c|c|c|c|c|c|c|c|c|c|}
\hline Cases & 1 & 2 & 3 & 4 & 5 & 6 & 7 & 8 & 9 \\
\hline \multicolumn{10}{|l|}{ Feed blend ratio and properties ${ }^{a)}$} \\
\hline [wt $\%]$ & 100 & 80 & 60 & 100 & 80 & 60 & 80 & 80 & 80 \\
\hline [wt $\%]$ & 0 & 20 & 40 & 0 & 20 & 40 & 20 & 20 & 20 \\
\hline Density at $15^{\circ} \mathrm{C}$ & 0.912 & 0.916 & 0.920 & 0.912 & 0.916 & 0.920 & 0.916 & 0.916 & 0.916 \\
\hline [wtppm] & 15500 & 12771 & 10067 & 15500 & 12771 & 10067 & 12771 & 12771 & 12771 \\
\hline Nitrogen & 700 & 777 & 854 & 700 & 777 & 854 & 777 & 777 & 777 \\
\hline \multicolumn{10}{|c|}{ Hydrotreatment conditions ( $1 \mathrm{~h}^{-1} \mathrm{LHSV} ; 500 \mathrm{Nm} l / \mathrm{m} l \mathrm{H}_{2} /$ oil ratio) } \\
\hline Temperature & 360 & 360 & 360 & 370 & 370 & 370 & 370 & 370 & 380 \\
\hline Pressure & 8 & 8 & 8 & 8 & 8 & 8 & 10 & 12 & 8 \\
\hline \multicolumn{10}{|l|}{ Hydrotreating product (FCC feedstock) } \\
\hline Density at $15^{\circ} \mathrm{C}$ & 0.886 & 0.889 & 0.898 & 0.882 & 0.885 & 0.896 & 0.883 & 0.887 & 0.885 \\
\hline [wtppm] & 1874 & 1541 & 1225 & 1247 & 1107 & 781 & 940 & 699 & 780 \\
\hline Nitrogen $(\mathrm{N})$ & 94 & 112 & 127 & 67 & 88 & 99 & 62 & 50 & 70 \\
\hline $524^{\circ} \mathrm{C}+$ yield by D $2887\left(524^{\circ} \mathrm{C}+\right)[\mathrm{wt} \%]$ & 7.9 & 7.3 & 6.4 & 8.0 & 6.8 & 6.1 & 6.3 & 6.4 & 6.0 \\
\hline Microcarbon residue $(M C R)$ & 0.04 & 0.05 & 0.05 & 0.02 & 0.02 & 0.04 & 0.01 & 0.01 & 0.02 \\
\hline \multicolumn{10}{|l|}{ Hydrocarbon types by GC-MS [wt } \\
\hline Saturates $(S A)$ & 61.4 & 62.4 & 58.3 & 66.6 & 65.1 & 60.5 & 69.3 & 69.8 & 63.7 \\
\hline Paraffins & 18.8 & 16.7 & 13.6 & 20.7 & 17.4 & 14.1 & 16.1 & 14.8 & 16.4 \\
\hline Cycloparaffins & 42.6 & 45.7 & 44.7 & 45.8 & 47.7 & 46.4 & 53.1 & 55.0 & 47.3 \\
\hline Mono- & 11.3 & 11.4 & 10.2 & 12.9 & 12.9 & 11.0 & 13.4 & 12.8 & 12.9 \\
\hline Di- & 11.2 & 12.0 & 11.8 & 12.3 & 13.3 & 12.5 & 15.0 & 14.8 & 13.3 \\
\hline Poly- & 20.0 & 22.4 & 22.6 & 20.6 & 21.5 & 23.0 & 24.8 & 27.4 & 21.0 \\
\hline Aromatics & 37.1 & 36.2 & 40.0 & 31.8 & 33.5 & 37.8 & 29.4 & 28.8 & 34.9 \\
\hline Mono- $(M A)$ & 26.2 & 24.7 & 27.4 & 24.1 & 23.7 & 26.5 & 24.0 & 21.7 & 26.3 \\
\hline Di- $(D A)$ & 6.7 & 6.9 & 7.9 & 6.0 & 6.3 & 8.1 & 4.3 & 5.4 & 6.6 \\
\hline Poly- & 4.1 & 4.6 & 4.8 & 1.7 & 3.5 & 3.1 & 1.2 & 1.7 & 2.0 \\
\hline Polars & 1.5 & 1.6 & 1.8 & 0.9 & 1.5 & 1.8 & 0.5 & 0.8 & 1.3 \\
\hline \multicolumn{10}{|l|}{$\begin{array}{ll}\text { FCC product yields }{ }^{\mathrm{b})} & {[\mathrm{wt} \%]}\end{array}$} \\
\hline Dry gas & 1.4 & 1.5 & 1.4 & 1.3 & 1.4 & 1.4 & 1.0 & 1.3 & 1.1 \\
\hline LPG & 15.9 & 16.3 & 15.5 & 16.6 & 16.6 & 15.8 & 16.6 & 17.2 & 15.9 \\
\hline Gasoline $\left(\mathrm{C}_{5}-216^{\circ} \mathrm{C}\right)$ & 58.8 & 58.6 & 58.1 & 59.8 & 59.2 & 58.6 & 60.5 & 60.1 & 59.5 \\
\hline $\mathrm{LCO}$ (light cycle oil; $216^{\circ} \mathrm{C}-343^{\circ} \mathrm{C}$ ) & 11.9 & 12.0 & 12.6 & 11.4 & 11.6 & 12.7 & 10.3 & 10.9 & 11.7 \\
\hline $\mathrm{HCO}$ (heavy cycle oil; $343^{\circ} \mathrm{C}+$ ) & 7.9 & 8.1 & 8.9 & 7.3 & 7.7 & 8.9 & 6.5 & 7.1 & 7.9 \\
\hline Coke & 1.9 & 2.0 & 2.0 & 1.9 & 1.9 & 2.0 & 1.8 & 1.8 & 1.9 \\
\hline Total & 97.8 & 98.5 & 98.6 & 98.2 & 98.4 & 99.4 & 96.5 & 98.5 & 98.1 \\
\hline
\end{tabular}

a) Feed properties calculated based on the blending ratio and individual properties given in Table 1 .

b) FCC product yields obtained by Eqs. (5) to (10), and not normalized to 100.0.

products. On the other hand, the OSV contains relatively higher nitrogen content which is less desirable in FCC feeds.

Employing a stepwise linear regression technique ${ }^{16)}$ using riser pilot plant data, correlations were previously developed to predict the FCC gasoline and coke yields from the feed properties at several standard operating conditions over a typical refinery-generated equilibrium catalyst $^{17)}$. The feeds were a typical Canadian conventional crude VGO and 9 VGOs from different upgrading processes of oil sands bitumen that covered a wide range of feed properties. The correlations have been used satisfactorily as a tool for evaluating the quality of the FCC feeds.

The following correlations are for gasoline and coke yields ${ }^{17)}$, as well as for other unpublished FCC product yields under typical conditions $\left(520^{\circ} \mathrm{C}\right.$ and $7.0 \mathrm{~g} / \mathrm{g}$ of catalyst/oil ratio):
Dry gas $(\mathrm{wt} \%)=10.995-0.0006326 \times N+$ $0.02599 \times\left(524^{\circ} \mathrm{C}+\right)-0.09223 \times S A-$

$$
0.1557 \times M A
$$

LPG $(\mathrm{wt} \%)=23.030-0.001920 \times N+0.03899 \times$ $\left(524^{\circ} \mathrm{C}+\right)-0.2752 \times M A$

Gasoline $\left(\mathrm{C}_{5}-216^{\circ} \mathrm{C}\right.$, wt $\left.\%\right)=37.316-0.004221 \times$

$N+0.2575 \times S A+0.2316 \times M A$

LCO (light cycle oil; $\left.216-343^{\circ} \mathrm{C}, \mathrm{wt} \%\right)=7.234+$ $0.001131 \times N+0.04817 \times\left(524^{\circ} \mathrm{C}+\right)+0.6187 \times$ $D A$

HCO (heavy cycle oil; $343^{\circ} \mathrm{C}+$, wt $\left.\%\right)=4.279+$ $0.004102 \times N-0.1037 \times\left(524^{\circ} \mathrm{C}+\right)+0.6012 \times$ $D A$

Coke $(\mathrm{wt} \%)=1.445+0.0005512 \times N+0.0630 \times$ $D A+0.4903 \times M C R$

where $N=$ nitrogen content $($ wtppm $) ; 524^{\circ} \mathrm{C}+=524^{\circ} \mathrm{C}+$ fraction determined by ASTM D 2887 simulated distillation (\%); $S A, M A, D A=$ saturates, and mono- and di- 
aromatics determined by GC-MS (wt\%); and $M C R=$ micro carbon residue $(\mathrm{wt} \%)$.

The correlations suggest that: (a) higher feed nitrogen results in lower yields of dry gas, LPG and gasoline; (b) higher saturates and monoaromatics result in higher gasoline yield; (c) higher diaromatics result in higher yields of LCO, HCO and coke; and (d) higher $M C R$ results in higher coke yield. The physical meaning of the correlations from the regression analysis was consistent with a study for ranking of the FCC feeds employing MAT (micro activity test) results ${ }^{18)}$.

The predicted FCC product yields determined by Eqs. (5) to (10) are summarized in Table 5. Each product yield was determined independently and was not normalized. The deviation from 100.0 may be considered as the bias of the results. Within the limits of such bias, the yield of gasoline slightly decreased with increased content of OSV at the expense of the yields of other products (see cases 1 to 3 and 4 to 6 ), but this can be overcome by slightly increasing the severity of the hydrotreatment (see cases 2, 5 and 9; 3 and 6 ; and 7 to 9), thereby increasing saturates and monoaromatics, decreasing nitrogen, $524^{\circ} \mathrm{C}+$ content, and $M C R$ in the hydrotreated products (or FCC feeds). In other words, blending VGO with OSV up to $40 \%$ as in this study would not adversely affect the FCC operation in conventional refineries.

\section{Conclusions}

Compared to Middle East crude oils, oil sands-derived SCO contains very low levels of sulfur and polyaromatics, and no residue, but contains relatively high levels of nitrogen and monoaromatics. Processability of the blends of Middle East crude distillates and distillates from SCO was investigated.

By blending the Middle East crude LGO with the oil sands-derived LGO, ULSD with on-spec $C N$ could be produced over commercially available typical $\mathrm{NiMo} /$ $\mathrm{Al}_{2} \mathrm{O}_{3}$ or $\mathrm{CoMo} / \mathrm{Al}_{2} \mathrm{O}_{3}$ catalysts under reasonable operating conditions. The $\mathrm{CO}$ and $\mathrm{HC}$ emissions from the blended LGO were slightly higher than those from $100 \%$ Middle East crude LGO, but $\mathrm{NO}_{x}$ emissions were lower. The effect of SCO blending on PM emissions was inconclusive. The $\mathrm{CO}, \mathrm{HC}$, and $\mathrm{PM}$ emissions could be correlated by total and polyaromatics, and clear cetane number (without additives).
By blending the Middle East crude VGO with the oil sands-derived VGO, the sulfur content was decreased that is beneficial in reducing the sulfur content of FCC products. The FCC yields were predicted based on the properties of the feeds (hydrotreated products) using previously prepared correlations. The yields of LPG and gasoline from the blended VGO decreased at the expense of light and heavy cycle oils under the same operating conditions, but the difference was insignificant and could be overcome by slightly increasing the severity of either the FCC pre-treater or the FCC unit.

Canadian oil sands-derived SCO can be used in conventional refineries and has beneficial effects for the production of clean automobile fuels.

\section{References}

1) Mortis, G., Oil \& Gas J., 44, June 7, (2004).

2) Yui, S., Chung, K. H., Oil \& Gas J., 46, April 23, (2001).

3) Mochida, I., Choi, K., J. Jpn. Petrol. Inst., 47, (3), 145 (2004).

4) Fujikawa, T., Kato, M., Kimura, H., Kiriyama, K., Hashimoto, M., Nakajima, N., J. Jpn. Petrol. Inst., 48, (2), 106 (2005).

5) Kouzu, M., Kuriki, Y., Hamdy, F., Sakanishi, K., Sugimoto, Y., Saito, I., Appl. Catal. A: General, 265, 61 (2004).

6) Yui, S., Chemical Industries Series \#58, eds. by Oballa, M. C., Shih, S. S., "Catalytic Hydroprocessing of Petroleum and Distillates," Marcel Dekker, (1994), p. 235.

7) Kabe, T., Ishihara, T., Qian, W., "Hydrodesulfurization and Hydrodenitrogenation," Kodansha, Tokyo (1999), p. 31-83.

8) Andari, M. K., Abu-Seedo, F., Stanislaus, A., Qabazard, H. M., Fuel, 75, (14), 1664 (1996).

9) Schulz, H., Bohringer, W., Waller, P., Ousmanov, F., Catal. Today, 49, 87 (1999).

10) Henry, H. C., Gilbert, J. B., Ind. Eng. Chem., Proc. Des. Dev., 12, 328 (1973).

11) Mears, D. E., Chem. Reactor Eng. ACS Monograph Series No. 133, 218 (1974).

12) Yui, S., AOSTRA J. of Research, 5, 211 (1989).

13) Choi, K.-H., Korai, Y., Mochida, I., Preprint Fuel Chem. Div. ACS, 48, 653 (2003).

14) Neill, W. S., Chippior, W. L., Gulder, O. L., Cooley, J., Richardson, E. K., Mitchell, K., Fairbridge, C., SAE Technical Paper, No. 2000-01-1856 (2000).

15) Shimazaki, N., Tsuchiya, K., Morinaga, M., Shibata, M., Shibata, Y., SAE Technical Paper, No. 2002-01-2824 (2002).

16) “SigmaStat User's Manual," Jandel Scientific Software, San Rafael, Calif. (1994).

17) Yui, S., Matsumoto, N., Sasaki, Y., Oil \& Gas J., 43, January 19 (1998).

18) Ng, S. H., Wang, G., Fairbridge, C., Zhu, Y., Yang, L., Ding, F., Yui, S., Energy \& Fuel, 18, 160 (2004). 
要 旨

中東原油とカナダ産オイルサンドビチューメンからの合成原油との混合処理

杉本 義一 ${ }^{\dagger 1}$, 相原 洋一 ${ }^{\dagger 2}$, 松村 明光 $^{\dagger 11}$, 大井 明彦 $^{\dagger 1)}$, 佐藤 信也 $^{\dagger 1}$, 斎藤 郁夫 $^{\dagger 1}$, 由井 聡文 $^{\dagger 3)}$

†1) (独) 产業技術総合研究所, 305-8565 茨城県つくば市東1-1-1つくば中央第5

†2)（独）産業技術総合研究所・NEDOフェロー，305-8565 茨城県つくば市東1-1-1つくば中央第5

${ }^{\dagger 3)}$ Syncrude Canada Ltd., 9421-17 Avenue, Edmonton, Alberta T6N 1H4, CANADA

カナダのオイルサンドビチューメンから製造された合成原油 をわが国で利用することを想定し，中東系直留軽油および減圧 軽油との混合水素化処理に扔ける脱硫・脱窒素反応性を調べる とともに，ディーゼル自動車排ガス組成への影響の把握，なら びに水素化処理した減圧軽油の FCC 原料油としての評価を 行った。

合成原油中の軽油留分は硫黄含有量が非常に低く，窒素や多 環芳香族分などの反応阻害物質が比較的少ないために, 中東系 直留軽油へ混合することにより, 水素化脱硫反応が促進され, 超深度脱硫（10 wtppm）軽油の製造が容易となった。中東系 ディーゼル燃料に水素化処理したオイルサンド系軽油を混合し た場合, $\mathrm{CO}$ および $\mathrm{HC}$ 排出量が増加する一方, $\mathrm{NO}_{x}$ 排出量が
減少したが, それらの増減量は小さかった。パティキュレート の排出量は, オイルサンド系軽油の添加と関係なく, 燃料中の 芳香族分の含有量に依存することがわかった。 減圧軽油の混合水素化処理では, 生成油の硫黄含量が減少す るものの窒素含量がやや増加した。原料油性状から FCC 分解 の生成物収率を予測した結果, オイルサンド系減圧軽油の混合 により LPG，ガソリン収率が減少するもののその影響は小さ いことがわかった。

オイルサンド系合成原油のわが国への導入は, 石油資源の安 定供給に資するばかりではなく, クリーンな自動車用燃料の製 造においても有益であることが示された。 